\title{
Analysis of the causes of crime: lenient punishment of the elderly
}

\author{
Jing CHEN \\ China University of Political Science and Law \\ Beijing, China
}

\begin{abstract}
According to the sixth national census data released the results of the main, the current size of the country's total population is about 1.37 billion, of which 0-14 year-old accounted for $16.6 \%$, which is 6.29 percentage points lower than the 2000 census; population aged 60 years and over accounted for $13.26 \%$, which is 2.93 percentage points higher than the 2000 census, and the population of which more than 65 years accounted for $8.87 \%$, which is 1.91 percentage points higher than the 2000 census indicator. In accordance with the division of population type of international standards, China had already entered the aging society. The society of population aging arrival, as well as the elderly population, whether absolute quantity or relative proportions of such a large, has brought many new problems to the community. As the elderly population increases, the empty nest family appeared and gradually increased, the elderly crime has gradually prominent. Physiological and psychological characteristics of the elderly population determine the elderly crime and have its unique law, characteristics, and reasons. It is suitable for elderly crime legislation, penal system, and penalties and the execution of sentences should have a different way from other crimes carried out against its particularity.
\end{abstract}

Keywords- elderly ;temper justice with mercy; Criminal Policy

\section{INTRODUCTION}

Meaning of Elderly commit a crime: Elderly crime, by definition, is a crime elderly implementation. This article talked about "elderly crime" which refers to the concept on criminology. At the same time, it also defines the concept of international jurists on many mainstreams consistent. For example, the definition of "German criminologist Schneider, Kaiser and Albrecht, the elderly crime: the sum of the elderly over 60 years of age and 60 years of age or older people implement criminal behavior. "Another criminologist Taiwan, China agrees" refers to older offenders over the age of 60 perpetrators. "This concept is in line with our usual understanding.

\section{ANALYSIS OF THE REASON OF ELDERLY CRIME LENIENT PUNISHMENT PRINCIPLE}

"Criminal responsibility is necessary to crime and the perpetrator of criminal responsibility, and the ability to identify and control their own behavior on the behavior of people with meaningful penalties." Thus, the criminal responsibility make up by the identify ability and controlling. Ability to identify and control the behavior of people understands their own behavior and the ability to control their own behavior. "Ability to identify, referring to the behavior of people know the contents of their own specific behavior, social significance of the results and capabilities, and can be a cognitive control ability, refers to the act or not to dispose of their implementation capacity to implement specific actions." Only acts also have the ability to identify and control the behavior of people that have criminal responsibility. Criminal responsibility is one of the subjective components of a crime, the responsibility ability in philosophy is the perpetrator of a subjective "know", but this "understanding" requires an objective "presence" to reflect the objective reality is that age. "Ability and responsibility of legal age are both unified and contradictory relationship "responsibility capacity needs the age to reflect, but age has not fully reflect the ability of responsibility. So bear the factors affecting the ability of criminal mainly includes three aspects: crime subject's age, physical condition and mental condition. As the subject of crime into older age: the physical function, physical function and major organ failure symptoms appear, showing hearing loss, vision changes, slow and other characteristics; on mental function, the "second childhood" return, lonely, sensitive, impulsive, irritable psychological characteristics in older crime people who show obvious. Compared with young offenders, older offender's cognitive ability and ability to control decreased, for the implementation of the same crimes and subjective social harm vicious also smaller than young adults. In summary, after the offender into old age, with age increasing, criminal responsibility dwindles until failure. "Criminal responsibility may have become the subject of crime and are held criminally responsible; even those who do not have the ability to implement a criminal act that endangers society objectively, it cannot become the subject of crime, and it cannot be held criminally responsible; criminal diminished capacity, its criminal responsibility is appropriate mitigation accordingly. "Older persons are in a weak position and criminal responsibility weakened in the social life, its commitment to the penalties should accordingly reduce. So for the elderly crime leniency applicable criminal penalties consistent with their ability should adapt to meet the criminal culpability, and this basic principle reflected the purpose of the substantive fairness of our criminal law. 


\section{ELDERLY CRIME LENIENT PENALTIES APPLICABLE PENALTIES IS CONSISTENT WITH HUMANITY}

As one of the basic concept of modern criminal law: criminal law humanity has been accepted and adopted by all countries and regions of the world. "And specific to the applicable penalties, humanity should include the following contents: (1) prohibit cruel punishment; (2) protection and respect the offender's basic human rights; (3) to help offenders return complex society." The most influential to offender motivation undoubtedly help re-offenders return to society. Older offenders due to aging, psychological physiological loss of affordability has to bear such a heavy penalty, even if they bear the penalty, it is difficult to return to society once again. Moreover, the elderly due to high age, remaining life is relatively short, the body weak, thus the long term despaired, will affect their enthusiasm to return to society and family. Compared with the average adult, it's even more cruelty of the same criminal penalties for older people. Therefore, the elderly crime lenient penalty applies in favor of reason and humanity embodied penalty, in line with the target value of the Criminal Code of the realization of humanity, highlighting the judicial doctrine of civilization and legal ethics.

\section{THE ELDERLY LENIENT CRIMINAL PENALTIES APPLICABLE COMPLY WITH THE SPECIAL PURPOSE OF PREVENTION AND GENERAL PREVENTION}

Special precautions penalty, prevention are generally two main aspects of preventive punishment. From the point of special prevention, the famous jurist Mr. Ma Kechang think that "special precautions include the following two aspects (1)transformation criminals become abandoned for good in the new, no further criminal activity; (2) elimination criminals, making it no longer a danger to society. "Prevention is a special branch of the death penalty for offenders deprived of the opportunity to make it a danger to society or to restrict free criminal offender applies to the possibility of loss within a certain period of danger to society. Because of elderly offender age, the physiological function of the recession, its subjective malignant and social risk, the possibility of recidivism is lower than the general adult offenders; if still on the older offender's sentenced to severe, non-discriminatory penalties lose penalties original education, reform of the significance and role. Elderly offender penalties applicable leniency special precautions you can achieve the purpose of punishment. On the other hand, generally refers to the prevention of crime through the imposition of penalties to achieve public guidelines, warning, and establish the authority of the criminal law, so then to maintain social stability. However, in general crimes of the public, crimes against the body weak elderly people who sympathized with compassion. Therefore, if the elderly and ordinary criminals sentenced to adult offenders indiscriminate punishment, the public tends to lose worship criminal law, criminal law considers inhumane, questioning the authority of the criminal law, but not conducive to achieving the purpose of general prevention penalty, and may lead to the new crime.

\section{ELDERLY CRIME LENIENT PENALTY APPLIES IN FAVOR OF IMPLEMENTING THE CRIMINAL POLICY OF COMBINING PUNISHMENT WITH LENIENCY}

\section{A. The main intension of the Criminal Policy}

Currently, the world's developed countries in terms of becoming more and more light punishment of criminal execution, socialization, produced certain results, and made a lot of experience with a reference value. 2006 Tenth Party Sixth Plenary Session will temper justice with mercy criminal justice policy identified as an important part of building a harmonious society, giving the criminal policy of combining punishment with leniency important strategic position, also for our criminal execution provides a new perspective. Temper justice with mercy is the basic policy of consistent implementation of criminal justice which is we fight against criminals and must adhere to the strategy. Under the guidance of this mainstream thinking, the criminal policy of combining punishment with leniency in the criminal justice be implemented gradually, over the years gradually introduced two high correlation of normative legal documents for the implementation of the criminal policy of combining punishment with leniency provide a basis. In May 2009 the Supreme Court issued the "People's Court of the Third Five-Year Reform Program (2009-2013)" in the proposed implementation of the criminal policy of combining punishment with leniency, as one of the important tasks of third five-year judicial reform. February 2010, the Supreme Court issued "a number of opinions on the implementation of the criminal policy of combining punishment with leniency" to judge how to implement the criminal policy of combining punishment with leniency in the criminal trial work to make specific provisions and specific requirements, made rules to follow.

\section{B. elderly people lenient criminal penalties applicable comply with The Criminal Policy}

In recent year, the elderly offender applies temper justice with mercy criminal policy further implemented in the rule of law. December 28, 2006, "a number of opinions on the implementation of temper justice with mercy in criminal prosecutions in policy," the elderly have adopted the provisions of criminal lenient punishment; February 8, 2010 the Supreme Court issued "on the implementation of the Criminal policy of views' in Article 21 clearly states is that "for the elderly crime, we must fully consider the motive for the crime, the purpose of the plot, as well as the consequences of repentance, etc., and combine the possibility of their dangerousness and recidivism, as appropriate be lenient punishment. "these normative documents suitable for elderly crime lenient penalties provided legal support to the specifications for the concrete practice of the theory. Crimes against the elderly lenient penalty are consistent with applicable temper justice with mercy criminal policy reflected in the following aspects: on the one hand, it is consistent with the criminal policy of combining punishment with leniency to protect human rights requirements. Bodily harm and harm to society than ordinary criminal offenders 
aged people with low "leniency" in line with the applicable penalties The Criminal Policy lenient requirements. Meanwhile vile crime, social harm large elderly offenders severely punished crime may prevent older people become more significant trend. For a long time, with China's cultural values are usually crimes against "excessive retaliation", and after the rise of the modern concept of punishment, from a human rights point of human nature demands against crime can only be "tit for tat" or called "limited retaliation", reflecting the guilt Suiting principle, however, the criminal policy of combining punishment with leniency in recent years, the judiciary has became mainstream academia recognize that the penalty than to punish crime, crime prevention, protection of human rights, in the penalty should reflect the humanitarian spirit. The vulnerable group for the elderly perpetrators of this penalty also should reflect the "people-oriented." "The Criminal Penalty Mitigation policy is discussed in the increasingly fierce international, mainstream penalties arising under more rational view of the background, so it is in tune with this international trend, advocates giving more humane care in judicial practice."Criminal Law Amendment (eight) in elderly crime against new regulations fully reflects the judicial humanitarian requirements, reflecting the impact of the criminal policy of combining punishment with leniency in crime subjective aspect that should be produced. Less than that, legislators also need to consider the same point with the general offender aged adult offenders and differences, further innovation in legislation, improved to fit the requirements of temper justice with mercy criminal policy.

\section{CONCLUSIONS}

Being suitable for elderly crime leniency is basic view in academic mainstream, mainly because the elderly lenient punishment and applying the basic principles of criminal law are the spirit of unity; crime and criminal law are consistent with the principle of adaptation, while it is also consistent special prevention and punishment the purpose. However, certain provisions of the Criminal Law Amendment Eight increase did not reach to build elderly crime punishment system, and not just on the substantive law and procedural criminal law or the Criminal Procedure Code with the relevant provisions of the elderly. If the investigation stage, the prosecution stage, and there are no special provisions for the elderly crime procedural characteristics, and this corresponds to juvenile delinquency, there is a wealth of regulations. Therefore, in the process of constructing elderly crime leniency mechanism cannot be confined to a single penalty applicable in the field, but should also be extended to the field of implementation of legislation and punishment, but also to try to legislate from both substantive and procedural aspects to improve. In criminal proceedings, the addition of the special nature of the provisions of the elderly crime during the execution of the sentence, and for the characteristics of the elderly can be relaxed for commutation, parole, pardon system suitable conditions for the elderly in the execution of punishment should be special provisions to meet the physical and psychological characteristics of the elderly. In the context of the criminal policy of combining punishment with leniency, need to discover hidden behind the penalty applicable system of social values, and the pursuit of political effects, social effects and the legal effect of unity on this basis.

\section{References}

[1] Jiusheng Xu: "German national study of crime," China Legal Publishing House, 1999, p. 245

[2] Ming Tsai Tun: "Criminal Psychology" (on), Dawn Taiwanese culture Company 1979, p. 171

[3] Tian Xueyuan editor: "Chinese elderly population (community)," Social Sciences Academic Press, 2007, p. 194 Luo Dahua criminal psychology [M] Beijing: masses Press 1986.48.

[4] [Germany] Schneider: "Criminology," Wu Xintao, Ma Yujun translation, Chinese People's Public Security University, 1990, p. 761-762

[5] Gao Mingxuan, Ma Kechang Criminal Law [M] Beijing: Peking University Press, Higher Education Press, 2005: 91

[6] Zhang Mingkai, criminal law, Beijing, Legal Publishing House, 2007 edition, page 251

[7] Zhang Mingkai, criminal law, Beijing, Legal Publishing House, 2007, p. 252

[8] Gao Mingxuan, Ma Kechang Criminal Law, Beijing: Peking University Press, Higher Education Press, 2000 edition 89

[9] Prof: "Criminal Law Philosophy", China University of Political Science and Law Press, 2004 edition, page 6

[10] Chen Caijuan: "On humanitarian penalty", contained "Law and Society", 20077

[11] Ma Kechang with: "Criminal Law" theory, Wuhan University Press, 1999, 62 - 63

[12] Supreme People's Court: Supreme People's Court on the issuance of the "People's Court of the Third Five-Year Reform Program (20092013)", the March 25, 2009, http: //www.chinacourt.org/public/detail.php? Id $=350101,2011$ on December 13 